\title{
A leatherback turtle's guide to jellyfish in the North East Atlantic
}

\author{
Thomas K. Doyle ${ }^{1, *}$, Jean-Yves Georges ${ }^{2,3}$ \& Jonathan D. R. Houghton ${ }^{4,5}$ \\ ${ }^{1}$ Coastal and Marine Resources Centre, ERI, University College Cork. \\ 2 Université de Strasbourg, IPHC. \\ ${ }^{3}$ CNRS. \\ ${ }^{4}$ School of Biological Sciences, Queen's University Belfast. \\ ${ }^{5}$ Queen's University Belfast Marine Laboratory. \\ *t.doyle@ucc.ie
}

\section{ABSTRACT}

Leatherback Dermochelys coriacea (Vandelli, 1761) sea turtles, are known to roam across entire oceans in search of high densities of their jellyfish food. Although this predator-prey relationship is well established, considerations of leatherback foraging behaviours are often hampered by a lack of information on the prey available to them in different regions. Therefore, to provide an overview for future studies we synthesise our current knowledge of jellyfish distributions and seasonality throughout the Northeast Atlantic and highlight known hotspots for the turtles themselves.

KEY WORDS: Dermochelys, gelatinous zooplankton, medusae, Rhizostoma, La Rochelle, Pelagia and salps.

\section{RESUMEN}

Las tortugas laúd Dermochelys coriacea (Vandelli, 1761), se conocen por recorrer océanos enteros, en busca de aprovisionamiento o alimento en zonas con grandes cantidades de zooplancton gelatinoso. Aunque la relación depredador-presa es bien conocida, el comportamiento de esta especie en relación a su alimentación es incompleta, debido a la falta de datos existentes en relación a la disponibilidad que existe de sus presas en las distintas regiones. Para proporcionar una visión general de la información relevante en este ámbito, hemos resumido el conocimiento que se tiene del zooplancton gelatinoso, su distribución y estacionalidad a lo largo del Noreste Atlántico y hemos querido resaltar puntos o zonas de especial importancia para las tortugas.

PALABRAS CLAVES: Dermochelys, zooplancton gelatinoso, medusae, Rhizostoma, La Rochelle, Pelagiay salpas.

\section{LABURPENA}

Larruzko dortokak Dermochelys coriacea (Vandelli, 1761), ozeanoetan barrena elikatzeko plankton lirdingatsuan aberats diren guneen bila ibiltzeagatik dira ezagunak. Naiz eta harrapakari-harrapakin harremana aski ezaguna izan, bere elikatzeko portaerak utsune handiak ditu oraindik, bere harrapakinen inguruko informazio ezagatik. Gai honekiko ikuspegi zabal bat ematearren, gaur egun zooplankton lirdingatsuaren inguruan dugun informazio esanguratsua laburbildu dugu artikulu honetan, Atlantiko Iparekialdean duen distribuzio eta urtaroaren arabeherako aldaketak eta bereziki itsas dortokentzat garrantzitsuak diren guneak azpimarratu nahi izan ditugu.

GAKO-HITZAK: Dermochelys, zooplankton lirdingatsua, medusae, Rhizostoma, La Rochelle, Pelagia eta salpak

\section{INTRODUCTION}

Jellyfish are one of the most abundant and easily recognisable organisms found in our coastal seas. Yet despite this familiarity, there is a general tendency to view such species as peripheral and transient components of marine systems that warrant little attention in their own right. This historical reluctance to understand the intricacies of jellyfish ecology and behaviour can lead to the assumption that all species function in a similar fashion or occupy the same niche within marine food webs. For example, the moon jellyfish Aurelia aurita (Linnaeus, 1758) (Fig. 1) is found in all coastal seas of the world and can be described as the quintessential jellyfish. Yet this species is just one of 1200 species of 'jellyfish' (Costello et al., 2008) that occupy the oceans, many of which are not suitable prey items for leatherbacks as they are simply too small or found at inaccessible depths. Moreover, many jellyfish have distinct habitat preferences and distinct trophic rules in much the same way as fish, so are correspondingly distributed in a far from random fashion (HOUGHTON et al., 2006a; DoyLE et al., 2007a). Here we provide an overview of the many different types of jellyfish available to foraging leatherback sea turtles in the Northeast Atlantic (NEA), make some general statements about their distribution and offer insights to biologists interested in jellyfish from a predator's perspective.

For the purposes of this paper, the term 'jellyfish' is used to describe a polyphyletic assemblage of medusae, siphonophores, ctenophores and urochordates (HADDOCK, 2004). Consequently, jellyfish should not be considered a taxonomic grouping but a disparate group of organisms that share many features such as transparency, fragility and a planktonic existence (HADDOCK, 2004). Jellyfish vary greatly in size from tiny hydromedusae less than a millimetre in diameter to large scyphomedusae measuring almost 2 metres across and $200 \mathrm{~kg}$ in weight (OMORI \& 
KITAMURA, 2004). Some jellyfish (siphonophores) have been described as some of the longest animals on the planet measuring 20 metres long (GODEAUx et al., 1998, in Bone 1998). This diversity of species is found in all oceans, from surface waters to the aphotic depths, with some eking out an unusual existence lying on the seafloor.

The manner in which jellyfish aggregate also varies markedly between species. Many form spectacular aggregations with many millions of individuals closely grouped, whereas other species are widely dispersed at much lower densities (GRAHAM et al., 2001). Taking this to the extreme, some animals which appear as individuals are in fact colonies such as the Portuguese Man-o-War Physalia physalis (Linnaeus, 1758) and Pyrosoma atlanticum (Péron, 1804) whilst other species can occur in both singular and colonial forms (e.g. salps). There is also great variation in life history of jellyfish with some species present only in the water column, whilst others with a metagenic life cycle are only brief members of the plankton, spending the rest of their lifecycle on the seabed as hydroids. Such differences between species must clearly be taken into account when considering the challenges facing leatherback turtles during their extensive foraging migrations, and as such we consider each major group in turn.
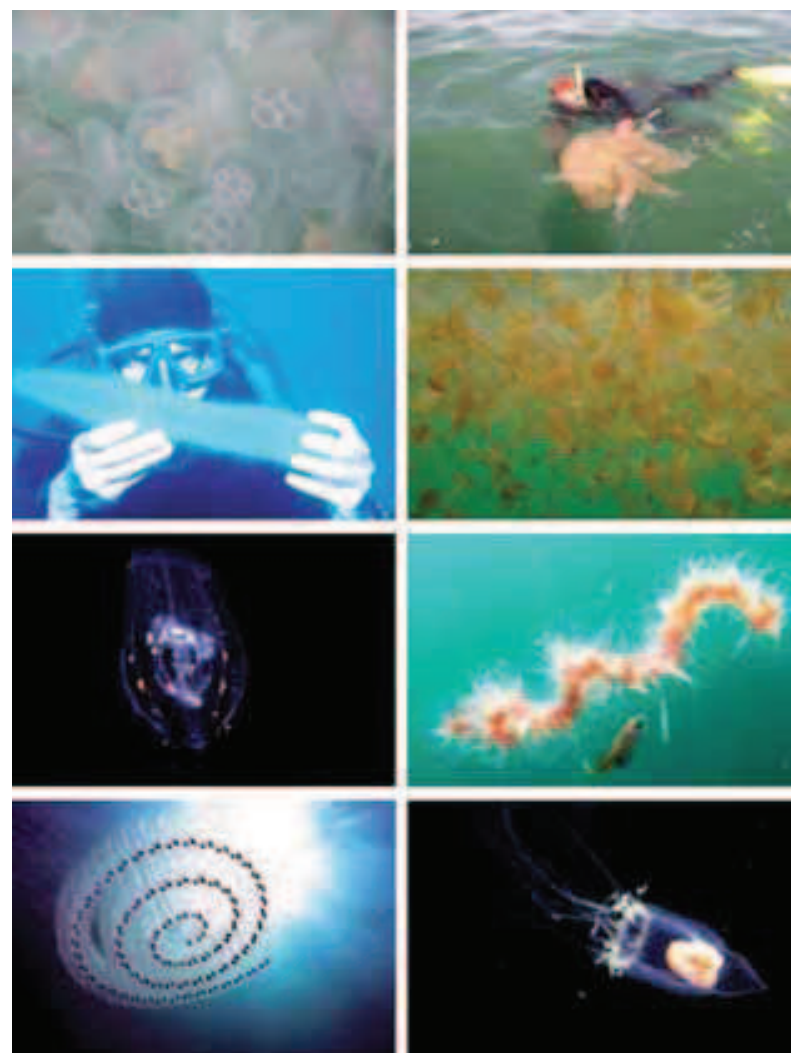

Fig. 1.- From top left clockwise: a scyphomedusae (Aurelia aurita) bloom (c) Michelle Cronin; large scyphomedusae (Rhizostoma octopus) with snorkeler (c) Thomas Bastian; oceanic scyphomedusae (Pelagia noctiluca) swarm (c Feargus Callagy; a siphonophore (Apolemia uvaria) (๑ Neil Hope; a hydromedusae ( Nigel Motyer; a salp chain ( Nigel Motyer; a ctenophore (Beroe) (c) Nigel Motyer; and a pyrosome (Pyrosoma) with diver (c) Peter Wirtz.

\section{THE MEDUSAE}

There are two types of medusae: scyphomedusae and hydromedusae. Scyphomedusae refers to what are generally known as 'true jellyfish' (HARDY, 1969). True jellyfish are the classic jellyfish (with a distinctive circular bell) typified by Aurelia aurita (Fig 1). There are 127 true jellyfish species spread across three orders: Orders Semaeostomeae, Rhizostomeae and Coronatae (COSTELLo et al., 2008). Most have a large $(>10 \mathrm{~cm})$ bell that is typically saucer shaped or hemi-spherical (RUSSELL, 1970). The bell can be very solid and along the margin of the bell, tentacles are normally found. These tentacles can be several metres long. A number of elongate structures (oral arms) hang from the centre of the bell and manubrium (RUSSELL, 1970). These oral arms may be thin and curtain like [as in Cyanea capiIlata (Linnaeus, 1758)] but may also be extremely robust making up $40 \%$ of the total mass of the jellyfish [e.g. Rhizostoma octopus (Linnaeus, 1758)] (DoYLE et al., 2008). As many scyphomedusae form large coastal aggregations (or blooms) with many thousands of individuals, they are probably the most important prey item for leatherback turtles when they are present in near-shore waters.

Most scyphomedusae have a complex life cycle characterised by a benthic polyp phase that periodically produces free swimming medusa during the spring and summer months (ARAl, 1997). These polyps are thought to be found on hard substrates such as rocky overhangs, mollusc shells and piers in relatively shallow waters, hence the neritic distribution for most scyphomedusae. An exception to this rule is the holoplanktonic scyphomedusae Pelagia noctiluca (Forsskål, 1775) which lacks a benthic polyp and occurs in both oceanic and neritic waters when climatic conditions dictate. P. noctiluca may be the most widely distributed scyphomedusae in our oceans, and often forms spectacular widespread blooms located over thousands $\mathrm{km}^{2}$ in varying densities. Deep-sea scyphomedusae include the coronates (generally $<10 \mathrm{~cm}$ bell diameter, but Periphylla periphylla (Péron \& Lesueur, 1810) can grow up to $20 \mathrm{~cm}$ ) which are likely to occur in most oceanic waters in the NEA (especially in the Rockall Trough area) at maximum abundance between 500 and 1500 m (RusSelL, 1970; MAuChline \& HarVEY, 1983; MAUCHLINE \& GORDON, 1991). Some coronates conduct diel vertical migrations, coming closer to the surface at night, but generally coronates appear to occur in low abundance (1-2 individuals $1000 \mathrm{~m}^{3}$, MAUCHLINE \& GORDON, 1991). Other deep-water scyphomedusae include the very large Stygiomedusa gigantea (Browne, 1910) which has been found in the Bay of Biscay area and can attain bell diameters of $100 \mathrm{~cm}$ and oral arms up to 100 cm long (Russell \& REES, 1960; BenfiELD \& GRAHAM, 2010).

Hydromedusae are often referred to as the 'little jellyfish' (HARDY, 1969). There are two broad types: holoplanktonic hydromedusae and meroplanktonic hydromedusae. The meroplanktonic hydromedusae [e.g. Obelia spp. and Phialella quadrata (Forbes, 1848)] are only found in the water column for short periods whereas their benthic hydroid stage may live for many years. Most 
are neritic in distribution, probably reflecting the distribution of their benthic hydroids. The holoplanktonic hydromedusae occur throughout the oceans and best typified by Aglantha digitale (O.F. Müller, 1776). Both types of hydromedusae are generally $>30 \mathrm{~mm}$ in size, and unless they occur in enormous blooms are unlikely to represent an important food source for leatherbacks. However, there are a few species of hydromedusae that grow to 10-30 $\mathrm{cm}$ in diameter [e.g. Aequorea spp. and Staurophora mertensii (Brandt, 1838)] that might be considered to be potential prey items. These species can be described in much the same way as the scyphomedusae i.e. they have a large saucer shaped bell with tentacles along the margin of the bell, but do not have oral arms.

\section{SIPHONOPHORES}

Siphonophores are colonial jellyfish that combine both polyps and medusae into a single organism. One species common to the North East Atlantic that best describes these organisms is Apolemia uvaria (Lesueur, 1815) (Fig. 1). This organism (colony) looks like a frayed rope and may be several metres in length. There are about 134 species of siphonophores and they are some of the longest animals in the world (COSTELLo et al., 2008). The majority of siphonophores are extremely fragile breaking into many pieces under the slightest of forces, thus restricting their distribution to oceanic environments where they do not come into contact with coastal hazards (currents, waves and hard substrates). There are some exceptions to this rule, for example Muggiaea atlantica (Cunningham, 1892) (and its 3 sibling species) are described as neritic, and are confined almost exclusively to near shore waters (MACKIE et al., 1987).

Through a combination of active swimming and perhaps some buoyancy control, many siphonophores are capable of diel vertical migration, especially many epipelagic species (MACKIE et al., 1987). Therefore, although siphonophores are certainly consumed by leatherbacks (DAVENPORT \& BALAZS, 1991), at times they may be too deep to be accessible to leatherbacks. Indeed, this diel vertical migration of siphonophores [generally located at depth during the day and migrate into surface waters at night (HOUGHTON et al., 2008)] has marked effects upon the diving behaviour of leatherbacks in more oceanic regions which typically wait for such prey to ascend to the top $200 \mathrm{~m}$ at night where the turtles can more readily feed upon them (HaYs et al., 2004; HOUGHTON et al., 2008).

There are three orders of siphonophores: Cystonectida, Physonectida and Calycophorida. All three orders have species that could represent prey items for turtles. Chief amongst them are the cystonects, with only two species: the Portuguese Man-O-War Physalia physalis and the Blue Bottle Physalia pacifica. These organisms have been described as aberrant siphonophores (HADDOCK, 2004) but are probably the most familiar and easily recognisable species. They float on the sea surface and have been reported in the literature as leatherback's prey items. The other two orders are more representative of si- phonophores i.e. long, thin and delicate strings of jelly. The calycophorans are generally small $(<20 \mathrm{~cm}$ long including siphosome) and have no float, whereas the cystonects have numerous swimming bells and a float. Cystonects have been found in the gut contents of leatherbacks and possibly an unidentified calycophoran too (Den HARTOG, 1980).

\section{CTENOPHORES}

There is a great diversity of body sizes and shapes in ctenophores. They can be egg shaped or ribbon-like, while others have large lobes or tentacles (HADDOCK, 2004) (Fig. 1). They range in size from a few millimetres to one metre in length, and can be found in coastal waters and to great ocean depths (HADDOCK, 2004). Many of them are extremely fragile and are therefore little studied given that collection in plankton nets is far from ideal. In contrast to all of the above taxa (i.e. medusae and siphonophores), ctenophores do not have cnidocytes, so do not sting. If tentacles are present they are adhesive. Most ctenophores are transparent and lack colour but most ctenophores are known to produce light (i.e. bioluminescence). It is not known whether ctenophores are a significant prey item for leatherback sea turtles. As many ctenophores are small and extremely fragile they may be unlikely prey for such large, visual predators. However, significant aggregations of ctenophores (e.g. in localised fronts) may offer suitable densities for prey consumption and should not be discounted.

\section{UROCHORDATES}

There are three types of urochordates that may represent prey for leatherback turtles. They are the doliolids, the salps and the pyrosomes. A fourth group, the appendicularians [e.g. Oikopleura dioica (Fol, 1872)] can be one of the most abundant members of the plankton at times (GORSKy \& FENAUX, 1998, in Bone 1998), but are typically too small to be considered as prey items. However, the other three groups all have members that in sufficient densities are certainly worthy of consideration in this context. Doliolids are the smallest taxa, generally no bigger than $40 \mathrm{~mm}$ and are predominantly found in the euphotic zone of continental shelf waters (PAFFENHÖFER et al., 1995). They are shaped like a barrel and have an extremely complex lifecycle.

At times doliolids can form extremely dense swarms (up to $100 \mathrm{~km}^{2}$ ) that last from days to weeks, with peak densities of 1000-5000 individuals $\mathrm{m}^{-3}$ (DEIBEL, 1998, in Bone 1998). Thus, although doliolids are small, such densities may offer 25-100 mg C m³ (DEIBEL, 1998, in Bone 1998), which is approximately equivalent to one large $R$ hizostoma octopus medusae per cubic metre (e.g. carbon content is $\sim 10 \%$ of dry mass, see CLARKE et al., 1992 and DOYLE et al., 2007b).

Salps are generally much bigger than doliolids, with some individuals typically $10 \mathrm{~cm}$ long but also capable of forming spectacular chains that may be metres long (Fig. 
1). They are often so abundant that they dominate the macroplankton with densities of $700 \mathrm{~m}^{-3}$ reported off the south west of Ireland in the top 100 m (BATHMANN, 1988). Many salp species are known to make extensive diel vertical migrations, for example Salpa aspera (Chamisso, 1819) performs migrations of $800 \mathrm{~m}$ amplitude (ANDERSEN, 1988 in Bone), and so in much the same way as siphonophores, their day time distribution may place them beyond the regular reach of leatherbacks.

Pyrosomes are one of the longest animals known, with $20 \mathrm{~m}$ long Pyrostremma spinosum (Herdman, 1888) having been observed (GodeAux et al., 1998, in Bone 1998). Generally, most pyrosomes are much smaller (typical sizes reported in literature range from $5-24 \mathrm{~cm}$ long, see Fig. 1; PerissinotTo et al., 2007; DriTs et al., 1992) but the ecology of pyrosomes is little studied. They do occur in warm open waters between $50^{\circ} \mathrm{N}$ and $50^{\circ} \mathrm{S}$ in all oceans (VAn SOESt, 1981, in PERISSINOTTO et al., 2007).

\section{TOP FIVE JELLYFISH HOTSPOTS IN THE NEA TO VISIT}

1) Rhizostoma hotspots. A recently discovered feature of some coastal embayments along Europe's Atlantic fringe is the large blooms of the barrel jellyfish, Rhizostoma octopus, which can contain tens of thousands of individuals (Houghton et al., 2006a). Considering that a single medusae, can measure up to $90 \mathrm{~cm}$ diameter and weigh as much as $35 \mathrm{~kg}$ it is unsurprising that the distribution of this species and sightings of leatherbacks in the Northeast Atlantic are closely linked (Houghton et al., 2006b). Unfortunately, for wide ranging leatherbacks these blooms do not occur everywhere and are only known to be consistently present in four areas in the NEA: La Rochelle/France, Carmarthen and Tremadoc Bays/Wales and Rosslare Bay/lreland) (LILLEY et al., 2009). The Solway Firth (UK) is probably another Rhizostoma hotspot but more surveys are required to fully corroborate this finding (HOUGHTON et al., 2006b). Provisional surveys around La Rochelle have revealed the highest densities recorded to date with 178 individuals observed during a 5-minute visual survey (from a $5.1 \mathrm{~m}$ Rigid Inflatable Boat) over a linear distance of $4.84 \mathrm{~km}$ (and with $7 \mathrm{~m}$ survey width) (DOYLE et al., unpublished data). Using bell diameter and wet weight measurements of Rhizostoma collected in the same locality (mean size and weight: $72.8 \pm 4.6 \mathrm{~cm}$ and $21.0 \pm 4.3 \mathrm{~kg}, \mathrm{n}=26$ ), this represents a surface density of $\sim 3730 \mathrm{~kg}$ (or $410,500.0 \mathrm{~kJ}$ of energy) of jellyfish in $0.3 \mathrm{~km}^{2}$ (or 30 hectares) (DoyLE et al., unpublished data).

2) Pelagia noctiluca swarms. Of an order of magnitude smaller than a mature Rhizostoma octopus, an individual $P$. noctiluca may not look like a substantial meal. However, considering the scale and 'swarming characteristics' of this species, a widespread bloom of $P$. noctiluca may represent a considerable feast. For example, recent observations by DoyLE et al., (2008) and BASTIAN et al., (2011) have demonstrated that this species may be located over an area 60,000 - 100,000 $\mathrm{km}^{2}$, from coastal areas through to oceanic waters. Jellyfish catch weights of $27.1 \mathrm{~kg}$.ha-1 were reported by BASTIAN et al. (2011). However, localised aggregations within the broader occurrence may provide good foraging conditions for leatherbacks. Indeed, when traversing across Langmuir cells that had recently developed, DOYLE et al. (2008) observed P. noctiluca aggregated the 2-4 m wide cells with densities of 100 $P$. noctiluca $\mathrm{m}^{-2}$. However, it should be noted that the mean size of $P$. noctiluca individuals was $14.0 \mathrm{~mm}$ (DOYLE et al., 2008).

3) Other coastal jellyfish blooms. Many coastal jellyfish species occur in high abundances over a range of scales. For a leatherback, encountering such features may be relatively easy e.g. locate coastline and then swim parallel to coast until a jellyfish bloom is encountered. Considering the patchiness of jellyfish (GRAHAM et al., 2001), encounters with high densities of jellyfish may be infrequent but observations by HougHTON et al. (2006a) and DoYLE et al. (2007) has shown that lower densities of large scyphomedusae may be more frequently encountered and even widespread. For example, surface observations of Chrysaora hysoscella (Linnaeus, 1767) and Aurelia aurita have been observed right across the Celtic Sea and Irish Sea respectively, at densities of 1300 individuals $\mathrm{km}^{-2}$ and 10600 individuals $\mathrm{km}^{-2}$ respectively.

4) Mesoscale features? A common feature of oceanic waters in the NEA is the occurrence of large mesoscale eddies. These can be cyclonic or anticyclonic and are typically 50-150 km in diameter (SHOOSMith et al., 2005). Such features are known to enhance productivity in oceanic waters (ISLA et al., 2004). As there are enhanced levels of productivity in these frontal areas it is likely too that there will be enhanced levels of gelatinous zooplankton. Indeed, a leatherback turtle satellite tracked in the NEA spent $\sim 66$ days in and around the edges of such a feature (DoyLE et al., 2008). Such residency in a mesoscale feature for several months implied that there were good foraging conditions. Indeed, such behaviour has been observed by other authors and for other sea turtle species with the conclusion that both warm and cold core eddies are associated with higher prey abundance (SHOOP \& KENNEY, 1992; LUTCAVAGE, 1996; LUSCHI et al., 2003; FERRAROLI et al., 2004; HAYS et al., 2006; ECKERT, 2006; Polovina et al., 2006). SuÁrez-Morales et al., (2002) found that there are significant differences in the gelatinous communities between inside and outside an eddy in the Gulf of Mexico.

5) Large swarms of salps. BATHMANN (1988) described massive swarm of Salpa fusiformis (Cuvier, 1804), west of Ireland. This is one of the highest densities of salps ever recorded. It is not known how common or frequent these occurrences are but if they operate in a similar fashion to blooms off the coast of North America where the areal extent of high densities of S. Aspera (Chamisso, 1819) was estimated to be $\sim 100,000 \mathrm{~km}^{2}$ 
(MADIN et al., 2006), then they may offer a substantial food resource to leatherbacks. Indeed a study by WITT et al. (2007) also revealed a high abundance of gelatinous zooplankton (which includes salps) in oceanic waters to the west and north west of Ireland.

\section{GENERAL POINTS OF CONSIDERATION}

A physical feature of the Atlantic is that both the continental slope and neritic waters are distributed in relatively narrow linear belts that run parallel to the coastlines of Europe and America (ANGEL, 1993). Within the neritic waters, the gelatinous zooplankton communities are dominated by large scyphozoans that have a benthic polyp stage. These species can be locally aggregated or widespread throughout the coastal seas. Moving from neritic waters to the continental slope and oceanic waters there is a distinct shift in the composition of gelatinous zooplankton communities from large robust scyphomedusae towards salps, doliolids and siphonophores (ANGEL \& PUGH, 2000). Furthermore, as we move north or south along these linear belts there may also be a change in species composition, species abundances and diversity. For example, there is a marked discontinuity in the top $1000 \mathrm{~m}$ of the North East Atlantic, between the more southerly (latitudes $11-40^{\circ}$ ) and the northern waters (latitudes 53-60') with higher numbers of specimens of calycophoran siphonophores in northern section but a greater diversity in the southern section (PuGH, 1986).

The distinct change between near-shore and oceanic gelatinous communities has marked implications for our interpretation of leatherback foraging patterns since leatherbacks have recently been shown to use both nearshore coastal, and open ocean foraging habitats when migrating in the Atlantic ocean (FossetTe et al., 2010). Accordingly, we must take care not to bias our perception of their feeding habits towards incidental observations of the species feeding on large surface medusae. For example, Houghton et al. (2008) in their study of deep diving in leatherback turtles proposed that post-nesting leatherbacks en route to productive temperate latitudes may feed upon deep, vertically ascending prey (siphonophores, salps, pyrosomes). Deep dives in this context were proposed as periodic speculation dives to visually locate prey patches deep in the water column in the absence of large aggregations of surface medusae (Houghton et al., 2008). The salient point here is that mid-water prey may form a more integral part of leatherbacks diet than once thought, prompting future studies of foraging behaviour in more remote locations.

Some comment must also be made about the seasonality of jellyfish prey available to leatherback turtles. The seasonal presence of leatherback turtles in the NEA is now well established with sightings and evidence from tracking studies suggesting that they are most abundant from late spring through to October. MCMAHON \& HAYS (2006) revealed that autumn movements away from temperate latitudes are primarily driven by decreasing water temperatures (i.e. turtles migrate south when waters typically cool below $16^{\circ} \mathrm{C}$ ). However, some consideration of prey availability is also warranted given that species with a metagenic life cycle (i.e. large coastal medusae) are typically absent from the water column during the autumn and winter, surviving to the next year as benthic polyps attached to the seabed. The emerging paradigm is that leatherbacks in the NEA overwinter at intermediate latitudes where oceanic prey such as siphonophores and pyrosomes may still be present (ANGEL \& PUGH, 2000), but water temperatures do not present a physiological challenge to the maintenance of body temperature.

\section{SUMMARY}

There are approximately 1200 species of jellyfish, however, perhaps only a fraction of this total are regularly consumed by leatherback turtles, the rest being too small, too sparsely aggregated or located too deep. The NEA must be considered as a mosaic of jellyfish landscapes ranging from large local aggregations and broadly dispersed populations of scyphomedusae in coastal areas and shelf seas, through to communities of salps and siphonophores in more oceanic waters. With this prey backdrop in mind it is easier to understand the foraging behaviour and migrations of leatherback sea turtles in the NEA.

\begin{tabular}{|c|c|c|c|c|c|c|c|}
\hline & Groups & $\mathrm{N}^{\circ}$ species & Typical size range & Bloom forming? & Distribution & Species of interest NEA & Evidence of feeding on? \\
\hline Scyphomedusae & $\begin{array}{l}\text { Semaeostomeae } \\
\text { Rhizostomeae } \\
\text { Coronatae }\end{array}$ & $\begin{array}{l}52 \\
56 \\
19\end{array}$ & $\begin{array}{l}10-60 \mathrm{~cm} \\
20-60 \mathrm{~cm} \\
<10 \mathrm{~cm}\end{array}$ & $\begin{array}{l}\text { Some } \\
\text { Most } \\
\text { No }\end{array}$ & $\begin{array}{l}\text { Coastal } \\
\text { Coastal } \\
\text { Mostly deepwater }\end{array}$ & $\begin{array}{l}\text { Aurelia aurita, Pelagia } \\
\text { noctiluca, Rhizostoma } \\
\text { octopus, Cyanea capillata, } \\
\text { Chrysaora hysoscella. }\end{array}$ & $\begin{array}{l}\text { Semaeostomeae (James \& HERMAN, 2001) } \\
\text { Rhizostomeae (DURON, 1978; HougHON et } \\
\text { al., 2006) } \\
\text { Coronatae - no evidence. }\end{array}$ \\
\hline Hydromedusae & $\begin{array}{l}\text { Holoplanktonic } \\
\text { Meroplanktonic } \\
\text { Neustonic }\end{array}$ & $\begin{array}{l}\sim 134 \\
100 \mathrm{~s} \\
1 \\
\end{array}$ & $\begin{array}{l}<10 \mathrm{~mm} \\
<10 \mathrm{~mm} \\
<10 \mathrm{~cm}\end{array}$ & & $\begin{array}{l}\text { Coastal + oceanic } \\
\text { Coastal } \\
\text { Oceanic }\end{array}$ & $\begin{array}{l}\text { N/A } \\
\text { Aequorea sp. } \\
\text { Velella velella }\end{array}$ & Possibly Aequorea sp. and Velella velella \\
\hline Siphonophores & $\begin{array}{l}\text { Physonect } \\
\text { Calycophorans } \\
\text { Cystonectida }\end{array}$ & $\begin{array}{l}2 \\
30+ \\
30+\end{array}$ & $\begin{array}{l}5-20 \mathrm{~cm} \\
5-100 \mathrm{~cm} \text { long } \\
5-100 \mathrm{~cm} \text { long }\end{array}$ & Some & $\begin{array}{l}\text { Neustonic } \\
\text { Oceanic + coastal } \\
\text { Oceanic }\end{array}$ & $\begin{array}{l}\text { Physalia physalis, } \\
\text { Muggiaea atlantica } \\
\text { Apolemia sp., }\end{array}$ & $\begin{array}{l}\text { Physonectida - BACom (1970) } \\
\text { Calycophoran (refs)- BRONGERSMA (1969) } \\
\text { Cystonectida - BRonGERSMA (1969) }\end{array}$ \\
\hline Ctenophores & All groups & 90 & $1-30 \mathrm{~cm}$ & Some & Oceanic mostly & & Possibly, see Collard, 1990 \\
\hline Urochordates & $\begin{array}{l}\text { Doliolids } \\
\text { Salps } \\
\text { Pyrosomes }\end{array}$ & $\begin{array}{l}20+ \\
15 \\
9\end{array}$ & $\begin{array}{l}<4 \mathrm{~cm} \\
1-15 \mathrm{~cm}^{*} \\
5-20 \mathrm{~cm}\end{array}$ & Many & Oceanic & Doliolum, Salpa, Pyrosoma sp. & $\begin{array}{l}\text { Doliolids - possibly, see Collard, } 1990 \\
\text { Salps - possibly, see Collard, } 1990 \\
\text { Pyrosomes (DavenPORT \& BALAzS, 1991) }\end{array}$ \\
\hline
\end{tabular}

Table 1.- Jellyfish groups and their presence in the NEA of arrival available were released. 


\section{ACKNOWLEDGMENTS}

TKD would like to acknowledge the assistance of Luke Harman (School of Biological, Earth \& Environmental Sciences, UCC), Thomas Bastian (Coastal and Marine Resources Centre, UCC) and Florence Dell'Amico (Aquarium La Rochelle) during the collection of Rhizostoma octopus surface densities. TKD was supported by an Irish Research Council for Science, Engineering and Technology (IRCSET) Fellowship and a Ulysses research grant. JYG was supported by Agence Nationale de la Recherche through the MIRETTE project (http://projetmirette.fr; ANR-07-JCJC-0122). TKD was also supported by the European Union Regional Development Fund (ERDF) under the Ireland Wales Programme 2007-2013 - Interreg 4A (EcoJel Project).

\section{REFERENCES}

ArAl, M. N. 1997. A functional biology of Scyphozoa. Chapman \& Hall. London.

Angel, M. V., Pugh, P. R. 2000. Quantification of diel vertical migration by micronektonic taxa in the northeast Atlantic. Hydrobiologia 440: 161-179.

Angel, M. V. 1993. Biodiversity of the pelagic ocean. Conserv. Biol. 7: 760-772.

ANDERSEN V. 1998. Salp and pyrosomid blooms and their importance in biogeochemical cycles. In: The biology of pelagic tunicates. Q. Bone (Ed.): 125-137. Oxford Univ. Press.

BAcon, P. R. 1970. Studies on the leatherback turtle Dermochelys coriacea (L.), in Trinidad, West Indies. Biol. Conserv. 2: 213-217.

Bastian, T., Stokes, D., Kelleher, J. E., Hays, G. C., Davenport, J., DOYLE, T. K. 2011. Fisheries bycatch data provide insights into the distribution of the mauve stinger (Pelagia noctiluca) around Ireland. ICES J. Mar. Sci. doi:10.1093 /icesjms/fsq178.

Bathmann, U. V. 1988. Mass occurrence of Salpa fusiformis in the spring of 1984 off Ireland: implications for sedimentation processes. Mar. Biol., 97: 127-135.

Benfield, M. C., Graham, W. M. 2010. In situ observations of Stygiomedusa gigantea in the Gulf of Mexico with a review of its global distribution and habitat. J. Mar. Biol. Ass. U. K. doi:10.1017/ S0025315410000536.

Clarke, A., Holmes, L. J, Gore, D. J. 1992. Proximate and elemental composition of gelatinous zooplankton from the Southern-Ocean. J. Mar. Biol. Ass. U. K. 155: 55-68.

ColLARD, S. B. 1990. Leatherback turtles feeding near a water mass boundary in the eastern Gulf of Mexico. Mar. Turtle Newsl. 50: 12-14.

Costello, J. H., Colin, S. P., DaBiRl, J. O. 2008. Medusan morphospace: phylogenetic constraints, biomechanical solutions, and ecological consequences. Invertebr. Biol. 127(3): 265-290.

Den Hartog, J. C. 1979. Notes on the food of sea turtles: Eretmochelys imbricata (Linnaeus) and Dermochelys coriacea (Linnaeus). Netherlands J. Zool. 30: 595-611.

Den Hartog, J. C., Van Nierop, M. M. 1984. A study on the gut contents of six Leathery turtles Dermochelys coriacea (Linnaeus) (Reptilia: Testudines: Dermochelyidae) from British waters and from the Netherlands. Zool. Verh. 209: 1-36.

DEIBEL, D. 1989. Feeding and metabolism of Appendicularia. In: The Biology of Pelagic Tunicates. Q. Bone (Ed.): 139-149. Oxford University Press, Oxford.
Drits, A. V., Arashkevich, E. G., Semenova, T. N. 1992. Pyrosoma atlanticum (Tunicata, Thaliacea): grazing impact on phytoplankton standing stock and role in organic carbon flux. J. Plankton Res. 14: 799-809.

DavenPort, J., Balazs, G. H. 1991. "Fiery pyrosomas" - are pyrosomas an important items in the diet of leatherback turtles?. Brit. Herp. Soc. Bull. 37: 33-38.

Doyle, T. K., Houghton, J. D., O'Súllleabháin, P. F., Hobson, V. J., MARNelL, F., DAVENPORT, J., HAYS, G. C. 2007. Leatherback turtles satellite-tagged in European waters. Endang. Species Res. 4: 23-31.

DOYle, T. K , De HaAs, H COTTON, D DORSCHEL, B Cummins, $V$, Houghton, J. D. R., Davenport, J., Hays, G. C. 2008. Widespread occurrence of the jellyfish Pelagia noctiluca in Irish coastal and shelf waters. Hydrobiologia 30: 963-968.

Doyle, T. K., Houghton, J. D. R., Buckley, S. M., Hays, G. C., DAVENPORT, J. 2007a. The broad-scale distribution of five jellyfish species across a temperate coastal environment. Hydrobiologia 579: 29-39.

DOYle , T. K., HOUghton, J. D. R., McDevitt, R. Davenport, J., Hays G. C. 2007b. The energy density of jellyfish: Estimates from bomb-calorimetry and proximate-composition. J. Exp. Mar. Biol. Ecol. 343: 239-252

Duron, M. 1978. Contribution à l'étude de la biologie de Dermochelys coriacea (Linné) dans les Pertuis Charentais. Doctoral Thesis. University of Bordeaux. Talence.

Ferraroli, S., Georges, J. Y., Gaspar, P., Le Maho, Y. 2004. Where leatherback turtles meet fisheries. Nature 249: 521-522.

Fossette, S., Hobson, V. J., Girard, C., Calmettes, B., Gaspar, P., GEORGES, J. Y., HAYS, G. C. 2010. Spatio-temporal foraging patterns of a giant zooplanktivore, the leatherback turtle. J. Mar. Syst. 81: 225-234

Godeaux, J., Bone, Q., Braconnot, J. C. 1998. Anatomy of Thaliacea. In: The biology of pelagic tunicates. Q. Bone (Ed.): 1-24. Oxford University Press. Oxford.

GodEAUX J. 1998. The relationships and systematics of the Thaliacea, with keys for identification In: The biology of pelagic tunicates. Q. Bone (Ed.): 273-294. Oxford University Press. Oxford.

GORSKY, G., FENAUX, R. 1998. The role of Appendicularia in marine food webs. In: The biology of pelagic tunicates. Q. Bone (Ed.): 161-169. Oxford University Press. Oxford.

Graham, W. M., Pages, F., Hamner, W. M. 2001. A physical context for gelatinous zooplankton aggregations: a review. Hydrobiologia 451: 199-212.

Hardy, A. C. 1956. The Open Sea: Its natural history: The World of Plankton. Collins. London.

Hays, G. C., Houghton, J. D. R., Myers, A. E. 2004. Endangered species: pan-Atlantic leatherback turtle movements. Nature 429: 522

Hays, G. C., Hobson, V. J., Metcalfe, J. D., Righton, D., Sims, D. W. 2006. Flexible foraging movements of leatherback turtles across the North Atlantic Ocean. Ecology 87: 2647-2656.

HADDOCK, S. H. D. 2004. A golden age of gelata: past and future research on planktonic ctenophores and cnidarians. Hydrobiologia 530/531: 549-556.

Houghton, J. D. R., DOyle, T. K., Davenport, J., Hays, G. C. $2006 a$ Developing a simple, rapid method for identifying and monitoring jellyfish aggregations from the air. Mar. Ecol. Prog. Ser. 314: 159-170. 
Houghton, J. D. R., Doyle, T. K., Wilson, M. W., Davenport, J., HAYs, G. C. 2006b. Jellyfish aggregations and leatherback turtle foraging patterns in a temperate coastal environment. Ecology 87: 1967-1972.

Houghton, J. D. R., Doyle, T. K., Davenport, J., Wilson, R. P HAYS, G. C. 2008. The role of infrequent and extraordinary deep dives in leatherback turtles (Dermochelys coriacea). J. Exp. Biol. 211: 2566-2575

Isla, J. A., Ceballos, S., Huskin, I., Anadon, R., Alvarez-Marques, F. 2004. Mesozooplankton distribution, metabolism and grazing in an anticyclonic slope water oceanic eddy (SWODDY) in the Bay of Biscay. Mar. Biol. 145: 1201-1212.

James, M. C., Herman, T. B. 2001. Feeding of Dermochelys coriacea on medusae in the northwest Atlantic. Conserv. Biol. 4: 202-205.

Lilley, M. K. S., Houghton, J. D. R., Hays, G. C. 2009. A review of distribution, extent of inter-annual variability and diet of the bloom-forming jellyfish Rhizostoma in European waters. J. Mar. Biol. Ass. U. K. 89: 39-48.

Luschi, P., Sale, A., Mencaccl, R., Hughes, G. R., Lutjeharms, J. R. E., PAPI, F. 2003. Current transport of leatherback sea turtles (Dermochelys coriacea) in the ocean. Proc. R. Soc. Lond. B 270: S129-S132.

Mackie, G. O., Pugh, P. R., Purcell, J. E. 1987. Siphonophore biology. Adv. Mar. Biol. 24: 97-262.

Madin, L. P Kremer, P Wiebe, P H Purcell, J E Horgan, E. H., Nemazie, D. A. 2006. Periodic swarms of the salp Salpa aspera in the Slope Water off the NE United States: Biovolume, vertical migration, grazing, and vertical flux. Deep-Sea Research / 53: 804-819.

Mauchline, J., Gordon, J. D. M. 1991. Oceanic pelagic prey of bethopelagic fish in the benthic boundary layer of a marginal oceanic region. Mar. Ecol. Prog. Ser. 74: 109-115.

Mauchline, J., Harvey, P. F. 1983. The Scyphomedusae of the Rockall Trough, northeastern Atlantic Ocean. J. Plankton Res. 5: 881-890.

McMahon, C. R., HAYS, G. C. 2006. Thermal niche, large-scale movements and implications of climate change for a critically endangered marine vertebrate. Glob. Change Biol. 12: 1330-1338.
Omori, M., Kitamura, M. 2004. Taxonomic review of three Japanese species of edible jellyfish (Scyphozoa: Rhizostomeae). Plankton Biol. Ecol. 51: 36-51.

Pugh, P. R. 1986. Trophic factors affecting the distribution of siphonophores in the North Atlantic Ocean. In: Pelagic biogeography. A. C. Pierrot-Bults, S. Van der Spoel, J. B. Zahuranec, R. K. Johnson (Eds.): 230-234. Proceedings of an International Conference, Technical Papers Marine Science, Unesco. Paris.

Paffenhöfer, G. A., Atkinson, L. P., Lee, T. N., Verity, P. G., BuLLUCK III, L. R. 1995. Distribution and abundance of thaliaceans and copepods off the southeastern U.S.A. during winter. Cont. Shelf Res. 15: 255-280.

Polovina, J. J., Uchida, I., Balazs, G., Howell, E. A., Parker, D. DutTon, P. 2006. The Kuroshio extension bifurcation region: a pelagic hotspot for juvenile loggerhead sea turtles. Deep-Sea Research // 53: 326-339.

Perissinotto, R., Mayzaud, P., Nichols, P. D., Labat, J. P. 2007. Grazing by Pyrosoma atlanticum (Tunicata, Thaliacea) in the south Indian Ocean. Mar. Ecol. Prog. Ser. 330: 1-11.

RusSELL, F.S. 1970. Pelagic Scyphozoa with a supplement to the first volume on hydromedusae. The medusae of the British Isles II. Cambridge University Press. Cambridge.

RusseLL, F. S., REES, W. J. 1960. The viviparous scyphomedusae Stygiomedusa fabulosa Russell. J. Mar. Biol. Ass. U. K. 39: 303-317

Shoosmith, D., Richardson, P. L., Bower, A. S., Rossby, H. T. 2005 Discrete eddies in the northern North Atlantic as observed by looping RAFOS floats. Deep-Sea Research I/ 52: 627-650.

Totron, A. K. 1965. A Synopsis of the Siphonophora. British Museum of Natural History. London, UK.

Witt, M J , Broderick, A C Johns, D. J Martin, C Penrose, R Hoogmoed, M. S., Godley, B. J. 2007. Prey landscapes help identify potential foraging habitats for leatherback turtles in the NE Atlantic. Mar. Ecol. Prog. Ser. 337: 231-244.

VAN SOEST, R. W. M. 1981. A monograph of the order Pyrosomatida (Tunicata, Thaliacea). J. Plankton Res. 3: 603-631. 